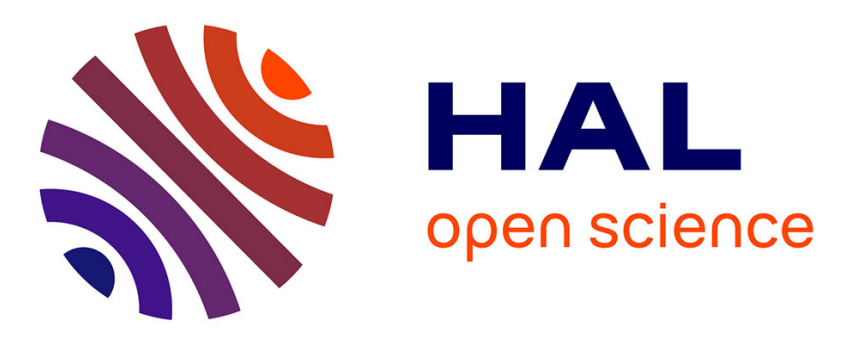

\title{
Combined GPR and Electrostatic Prospection in the Roman Colony of Vienna (France)
}

\author{
Christophe Benech, Benjamin Clément, Michel Dabas, Lionel Darras, \\ Sébastien Flageul, Côme Parfant, Lola Perruchon-Monge, Cyril Schamper, \\ Alain Tabbagh, Quentin Vitale
}

\section{To cite this version:}

Christophe Benech, Benjamin Clément, Michel Dabas, Lionel Darras, Sébastien Flageul, et al.. Combined GPR and Electrostatic Prospection in the Roman Colony of Vienna (France). Archeosciences, revue d'Archéométrie, 2021, XIVth International Conference of Archaeological Prospection, 45-1, pp.27-30. 10.4000/archeosciences.8180 . halshs-03362315

\section{HAL Id: halshs-03362315 \\ https://shs.hal.science/halshs-03362315}

Submitted on 4 Oct 2021

HAL is a multi-disciplinary open access archive for the deposit and dissemination of scientific research documents, whether they are published or not. The documents may come from teaching and research institutions in France or abroad, or from public or private research centers.
L'archive ouverte pluridisciplinaire HAL, est destinée au dépôt et à la diffusion de documents scientifiques de niveau recherche, publiés ou non, émanant des établissements d'enseignement et de recherche français ou étrangers, des laboratoires publics ou privés. 


\section{COMBINED GPR AND ELECTROSTATIC PROSPECTION IN THE ROMAN COLONY OF VIENNA (FRANCE)}

Christophe Benech, Benjamin Clément, Michel Dabas, Lionel Darras, Lionel Flageul, Côme Parfant, Lola Perruchon-Monge, Cyril Schamper, Alain Tabbagh, Quentin Vitale

Presses universitaires de Rennes | «ArcheoSciences »

2021/1 n 45-1 | pages 27 à 30

ISSN 1960-1360

ISBN 9782753585874

DOI 10.4000/archeosciences.8180

Article disponible en ligne à l'adresse :

https://www.cairn.info/revue-archeosciences-2021-1-page-27.htm

Distribution électronique Cairn.info pour Presses universitaires de Rennes.

(C) Presses universitaires de Rennes. Tous droits réservés pour tous pays.

La reproduction ou représentation de cet article, notamment par photocopie, n'est autorisée que dans les limites des conditions générales d'utilisation du site ou, le cas échéant, des conditions générales de la licence souscrite par votre établissement. Toute autre reproduction ou représentation, en tout ou partie, sous quelque forme et de quelque manière que ce soit, est interdite sauf accord préalable et écrit de l'éditeur, en dehors des cas prévus par la législation en vigueur en France. Il est précisé que son stockage dans une base de données est également interdit. 


\section{ArcheoSciences}

Revue d'archéométrie

\section{Combined GPR and Electrostatic Prospection in the Roman Colony of Vienna (France)}

Christophe Benech, Benjamin Clément, Michel Dabas, Lionel Darras, Lionel Flageul, Côme Parfant, Lola Perruchon-Monge, Cyril Schamper, Alain Tabbagh and Quentin Vitale

\section{(2) OpenEdition}

Journals

Electronic version

URL: https://journals.openedition.org/archeosciences/8180

DOI: 10.4000/archeosciences.8180

ISSN: 2104-3728

\section{Publisher}

Presses universitaires de Rennes

\section{Printed version}

Date of publication: 16 August 2021

Number of pages: $27-30$

ISBN: 978-2-7535-8587-4

ISSN: 1960-1360

Electronic distribution by Cairn

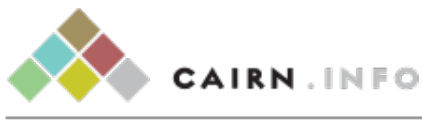

CHERCHER, REPÉRER, AVANCER

\section{Electronic reference}

Christophe Benech, Benjamin Clément, Michel Dabas, Lionel Darras, Lionel Flageul, Côme Parfant, Lola Perruchon-Monge, Cyril Schamper, Alain Tabbagh and Quentin Vitale, "Combined GPR and

Electrostatic Prospection in the Roman Colony of Vienna (France)", ArcheoSciences [Online], 45-1 | 2021, Online since 16 August 2021, connection on 30 August 2021. URL: http://

journals.openedition.org/archeosciences/8180 ; DOI: https://doi.org/10.4000/archeosciences.8180 


\title{
Combined GPR and Electrostatic Prospection in the Roman Colony of Vienna (France)
}

\author{
Christophe Benech ${ }^{a}$, Benjamin Clément ${ }^{b}$, Michel Dabas $^{c}$, Lionel Darras ${ }^{\mathrm{d}}$, \\ Lionel Flageul $^{e}$, Côme Parfant ${ }^{d}$, Lola Perruchon-Monge ${ }^{d}$, Cyril Schamper ${ }^{f}$, \\ Alain TABBAGH ${ }^{\mathrm{f}}$ and Quentin VITALE ${ }^{\mathrm{g}}$
}

\begin{abstract}
Highlights:
- Electrical resistivity and dielectric permittivity mapping using an electrostatic survey device.

- GPR delineation of probable ancient anchor point of the ancient bridge.

- Combination of GPR and electrostatic surveys for urban archaeology.
\end{abstract}

Keywords: GPR, Electrostatic device, urban survey, Roman archaeology.

\section{THE SITE}

The Roman colony of Vienna is located at the site of the current city of Vienne (Isère), on the left bank of the river Rhône, at its confluence with the Gère tributary river. It was probably founded by Emperor Octavian between 40 and 27 BC. From the Augustan period, the distinctive features of Roman town planning made their appearance and developed (forum, temple of Rome and Augustus, basilica, theater, rampart) along with a road network, which overlaid partially the axes of the Gallic village. It was also at this time that the suburban district of Saint-Romain-en-Gal was set up, along a wide road coming from Lyon. Under the reign of Claudius, the town planning seems to experience a new growth, which could be partly linked to the consequences of an earthquake that struck the city under Caligula (Adjadj et al., 2014: 119-128). It was at this time that the outskirts of the city reached their final extension while the road network was definitively defined.

The geophysical surveys carried out throughout the suburban area of ancient Vienne concerned four sectors: the socalled "Palais du Miroir", probably former thermal baths of Saint-Romain-en-Gal; the district of Sainte-Colombe where excavations, carried out in 2017, allowed the exploration of an entire district located at the outlet of the southern bridge (Clément, 2019); the right bank of the river Rhône for looking at the location of the bridge which allowed the crossing of the river, and finally the southern district of Vienne, which included a circus and a warehouse area.

\footnotetext{
${ }^{a}$ Corresponding author, Université de Lyon, CNRS, Archeorient, UMR 5133, Maison de l'Orient et de la Méditerranée, France

b Université de Franche-Comté, CNRS, Chrono-Environemment, UMR 6249, Besançon, France

' PSL University, CNRS, AOROC, UMR 8546, ENS, 75005 Paris, France

' Université de Lyon, CNRS, Archeorient, UMR 5133, Maison de l'Orient et de la Méditerranée, France

' Sorbonne Université, UMR SU CNRS EPHE 7619 METIS, Paris, France

f Sorbonne Université, UMR SU CNRS EPHE 7619 METIS, Paris, France

' Éveha International, 161 avenue de Verdun, 94200 Ivry-sur-Seine, FranceUniversité de Lyon, CNRS, Archeorient, UMR 5133, Maison de l'Orient et de la Méditerranée, France
} 


\section{Methods}

These surveys were carried out using electrostatic and ground-penetrating radar methods. The electrostatic method can be presented as a generalization of the electrical method (Grard \& Tabbagh, 1991) where four electrostatic poles, placed in contact with the ground, are used to inject the current and to measure the resulting potential difference. Therefore, the electrical resistivity and the dielectric permittivity (polarization capacity) can be estimated without needing to plant electrodes in the ground, when the latter has a value high enough. As it is the case for the electrical method, its sensitivity to pipe and cable utilities is very low, which is very advantageous in complex urban contexts.

The two electrostatic devices which were used during the prospecting in Vienne are:

- The "sliding carpet" (Fig. 1a) which above all makes it possible to carry out profiles (or sliding sounding) in the streets with an investigation depth of up to 3 to $4 \mathrm{~m}$ (less if the most superficial layers are electrically conductive). The current version was recently used in Larnaca (Cyprus) to locate the old rampart of the town of Kition (Benech et al., 2017), and in Sweden to identify areas of low electrical resistivity indicating potential areas of strong corrosion (salt infiltration) of the district heating network (Rejkjær et al., 2020).

- The "MP3" (Fig. 1b) which is primarily designed to perform mapping with a maximum investigation depth of around $2 \mathrm{~m}$. The current version (Flageul et al., 2013) was recently used for archaeological purposes on the Grande Place in Brussels (Blary et al., 2018), together with ground penetrating radar measurements.

The ground penetrating radar device used in the field is a Stream X multi-antenna from IDS GeoRadar (Fig. 1c). It consists of an array of 8 antennas, operating at a center frequency of $200 \mathrm{MHz}$ and spaced $12 \mathrm{~cm}$ apart. This configuration allows high-resolution recording of the amplitude of reflection of electromagnetic waves in the ground over a width of $72 \mathrm{~cm}$ in one pass.

The surveys consisted of a series of profiles in the streets intersecting the sought-after structures (streets, circus, basement of the bridge, building foundations). Only the sectors of Sainte-Colombe and the "Palais du Miroir" could be the subject of more extensive exploration by mapping.

\section{Results}

The surveys carried out in July 2020 were a first exploratory step in the use of geophysical methods for the study of
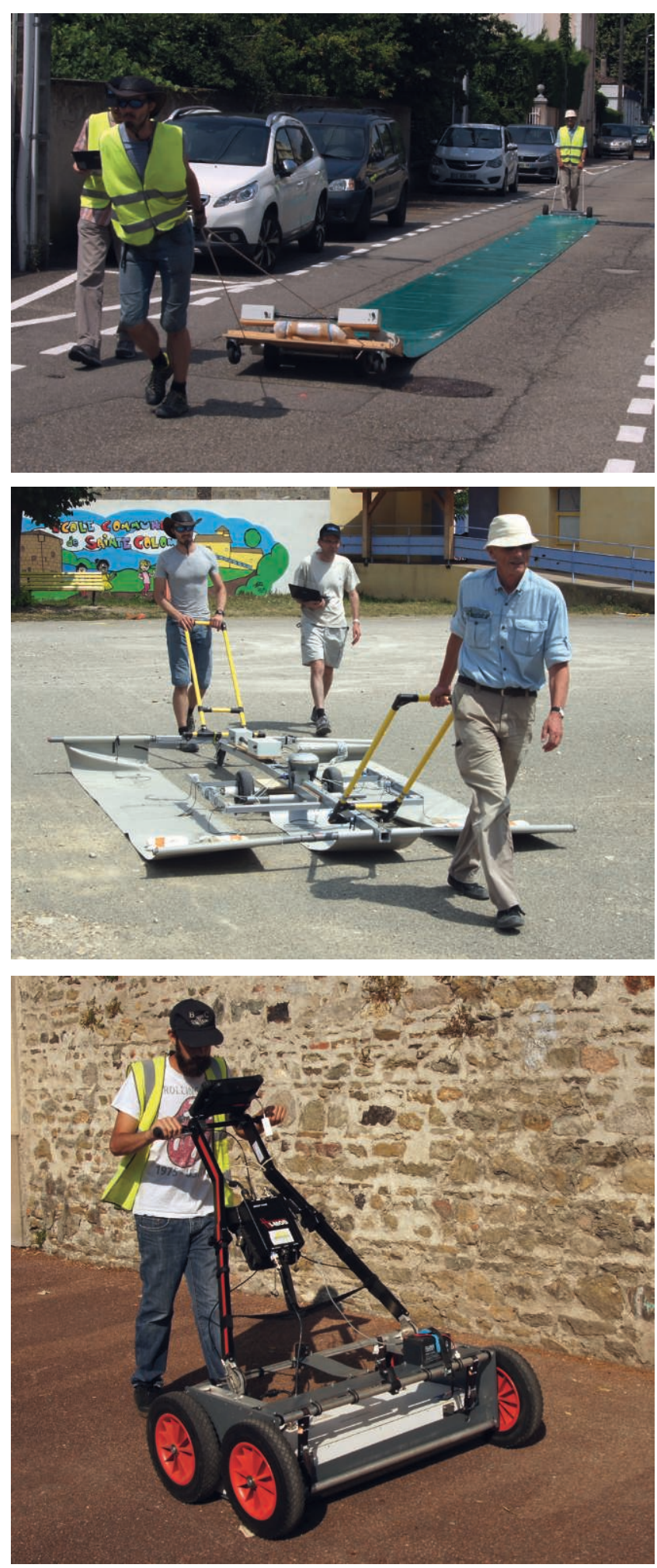

Figure 1. Geophysical devices used during the survey: a) Electrostatic "sliding carpet", b) Electrostatic MP3, c) IDS Georadar (Stream X V8). 


\section{St Colombe quay}

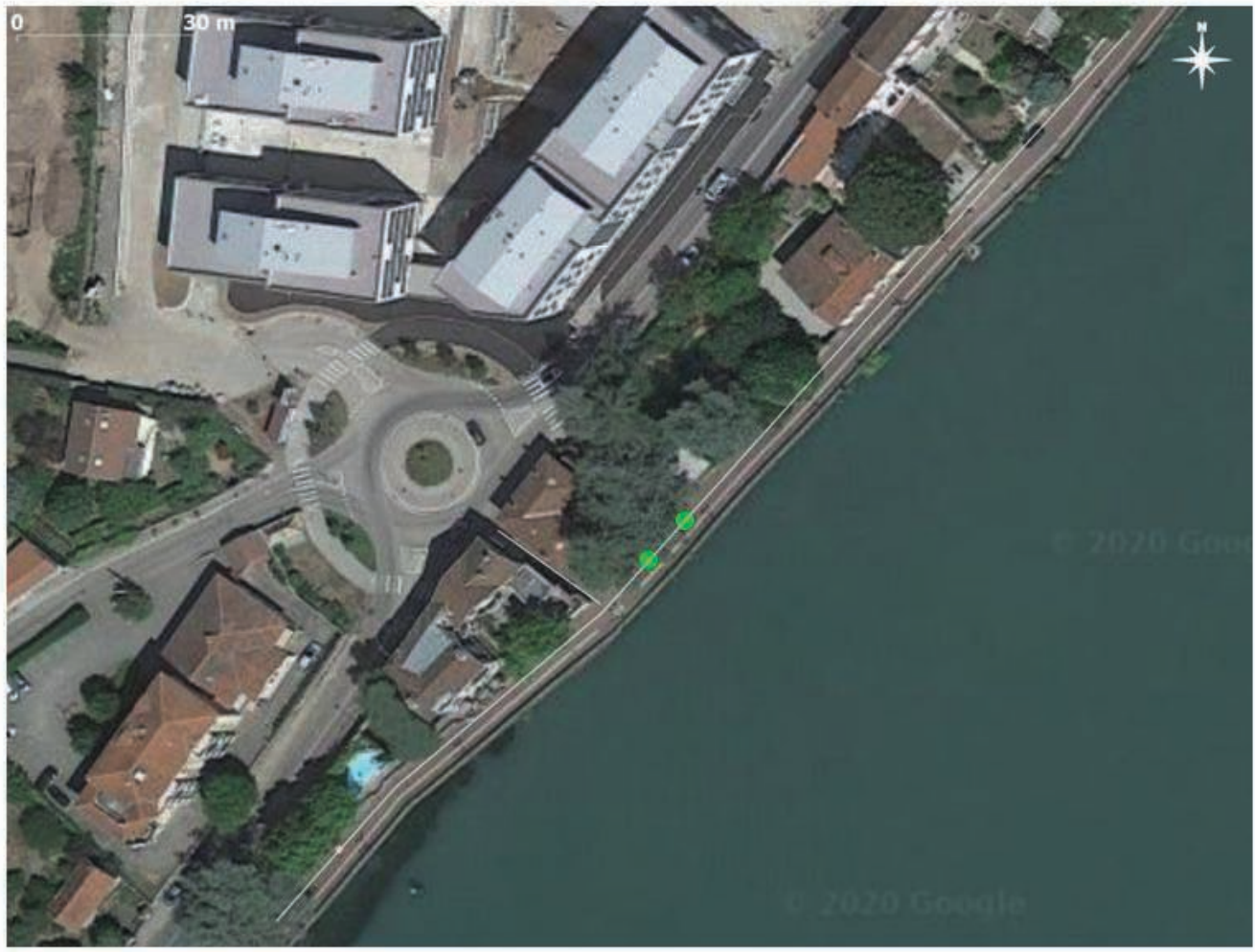

Sliding carpet - Channel 1

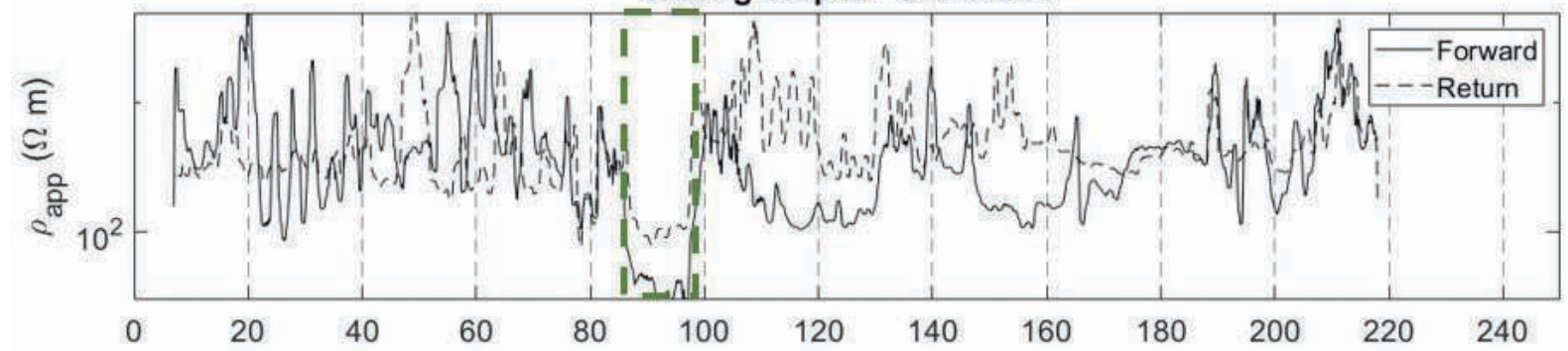

Sliding carpet - Channel 2

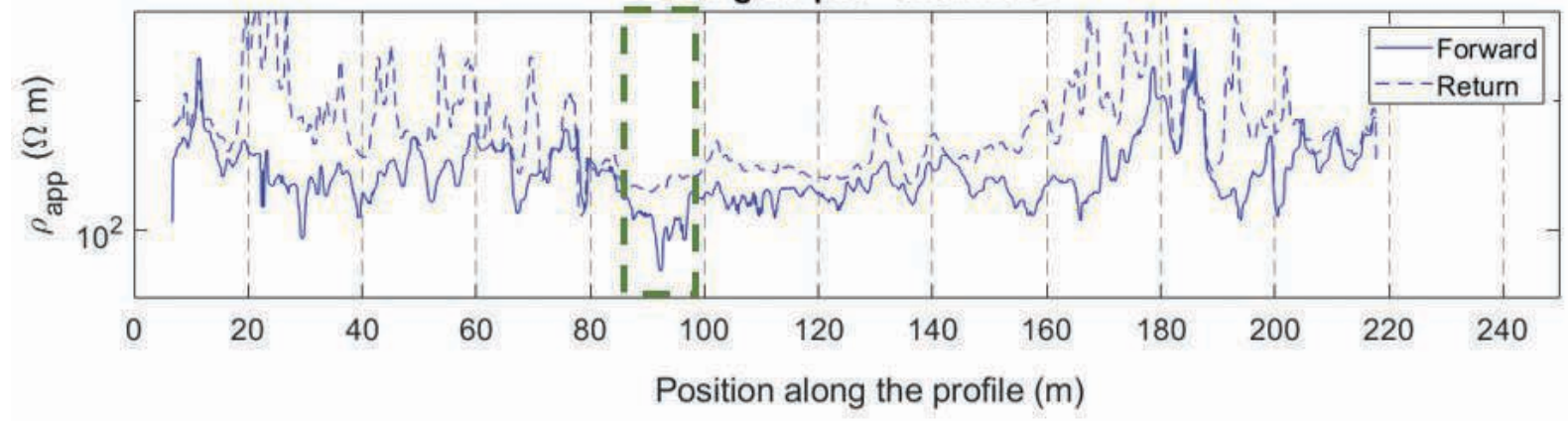

Figure 2a. Profiling along the Saint-Colombe quay: Apparent resistivities from the first two channels of the electrostatic carpet device (forward and backward). 


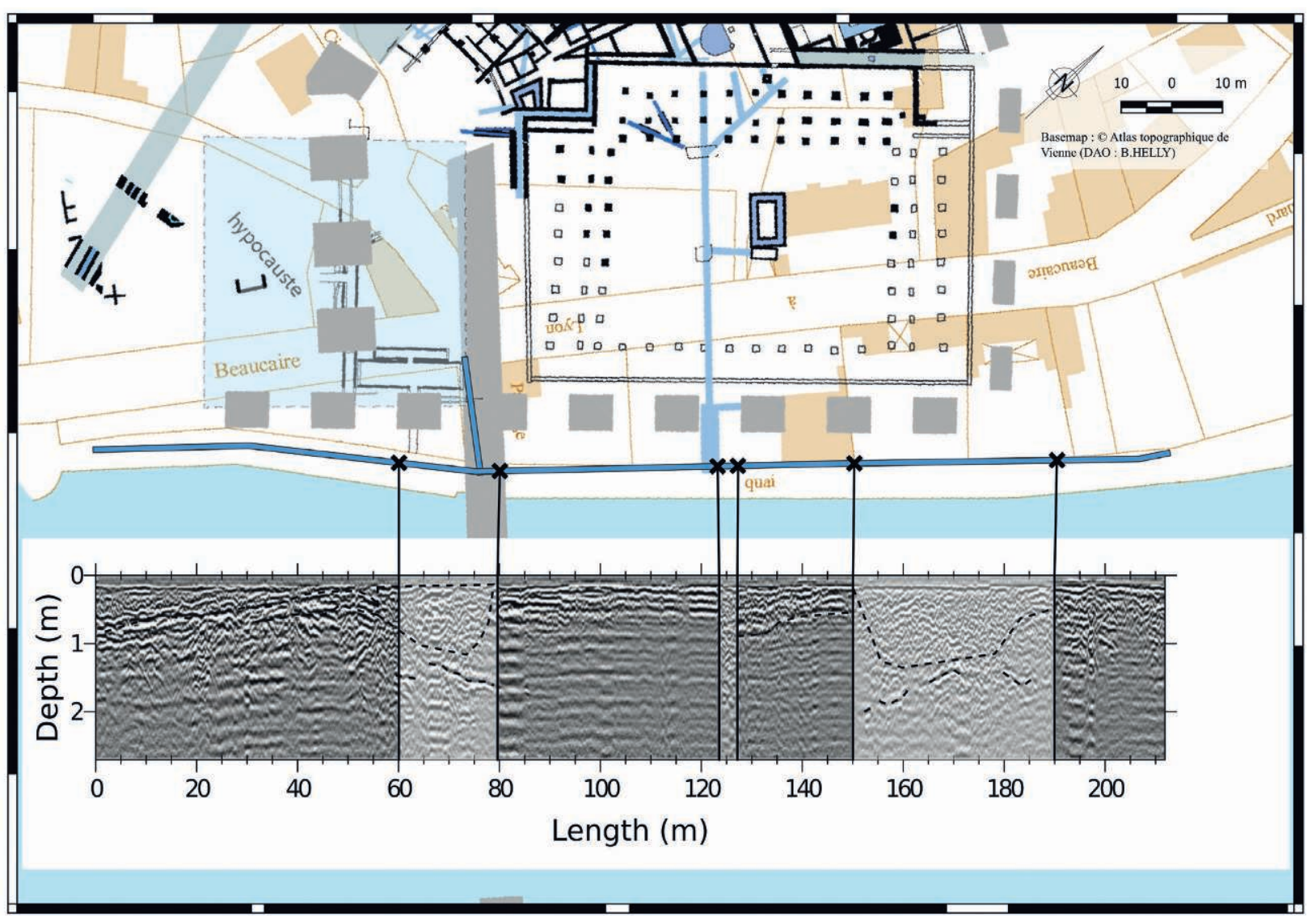

Figure 2b. Profiling along the Saint-Colombe quay: GPR time slice.

ancient topography in the municipalities of Vienne, SainteColombe and Saint-Romain-en-Gal. The objective of this preliminary study was to estimate the performance of the two geophysical methods, mainly used in modern urban settings, namely the electrostatic method and the ground penetrating radar method, according to the environmental and archaeological context of the different sectors.

It was in the southern sector of the ancient city of Vienne that the most interesting results were obtained: geophysical exploration made it possible to identify several streets and specify the location of the circus. On the quays of the right bank, the profiles produced have identified a sector that could be the anchor point of the ancient bridge (Fig. 2), in agreement with other archaeological evidence.

\section{References}

Adjadj, F., 2013. Vienne, 38/2, Carte archéologique de la Gaule, Académie des Inscriptions et Belles-Lettres, 555 p.

Benech, C., Audebert, M., Chevalier, A., Darras, L., Flageul, S., Fourrier, S., Rabot, A., Rejiba, F., Schamper, C., Tabbagh, A., 2017. Revealing the topography of the Ancient Kition
(Larnaka, Cyprus): an integrated approach, $12^{\text {th }}$ International Conference of Archaeological Prospection (University of Bradford, UK, 12-16 September).

Blary, F., Sosnowska, P., Charruadas, P., Van Nieuwenhove, B., Dabas, M., Flageul, S., Tabbagh, A., 2018. Prospection de la "grand place " de Bruxelles : utilisation de la méthode électrostatique, $11^{\mathrm{e}}$ colloque GEOFCAN (Antony, France, 20-21 novembre).

Clément, B., 2020. Un quartier antique de la colonie romaine de Vienne figé par les flammes. Premiers résultats des fouilles du Bourg à Sainte-Colombe, Bulletin de la SFAC, XLX, 20182019, Revue Archéologique, 69(1), 185-191.

Flageul, S., Dabas, M., Thiesson, J., Rejiba, F., Tabbagh, A., 2013. First in situ tests of a new electrostatic resistivity meter, Near Surface Geophysics, 11(3), 265-274.

Grard, R., Tabbagh, A., 1991. A mobile four electrode array and its application to the electrical survey of planetary ground at shallow depths, Journal of Geophysical Research, 96, 4117-4123.

Rejkjær, S., Finco, C., Schamper, C., Rejiba, F., Tabbagh, A., König, J., Dahlin, T., 2021. Determination of the resistivity distribution along underground pipes in urban contexts using galvanic and capacitive methods, Near Surface Geophysics, 19, 27-41. 